\title{
Declining needs for total joint replacements for rheumatoid arthritis
}

\author{
Nasim A Khan 1 and Tuulikki Sokka*2 \\ See related research by Hekmat et al., http://arthritis-research.com/content/13/2/R67
}

\begin{abstract}
This millennium brings new views to rheumatology. Total joint replacement surgery is needed less often as active treatment strategies combined with availability of new medications has led to more effective rheumatoid arthritis control. This was beautifully shown in a recent issue of Arthritis Research \& Therapy by a Swedish study that uses data from national registers and compares incidence rates for total hip and knee arthroplasties before and after the establishment of biologic agents use for rheumatoid arthritis
\end{abstract}

Total joint replacement (TJR) surgery was a milestone in rheumatology. Patients whose inflammatory joint disease once confined them to a wheelchair or bed received a new joint and were able to walk. But 50 years later, approaches have changed. A current trend, as reported by Hekmat and colleagues [1] in a recent issue of Arthritis Research \& Therapy, is to gather evidence that TJR is not needed for patients with rheumatoid arthritis (RA) as inflammation and consequent damage can be kept under control with improved medications.

A need for a TJR of the hip or knee has been a severe long-term consequence for patients with RA. Wolfe and Zwillich [2] estimated that $25 \%$ of all RA patients who were under observation between the 1970s and 1990s needed TJR surgery over two decades.

Concomitantly with an increasing use of early and active treatment strategies, the clinical status of patients with RA has improved in comparison with previous decades. Even before the era of biologic treatments, improvements were seen in patients' clinical status as measured by disease activity, functional capacity, radiographic scores, and other clinical parameters [3].

${ }^{*}$ Correspondence: tuulikki.sokka@ksshp.fi

${ }^{2}$ Arkisto/Tutkijat, Jyväskylä Central Hospital, 40620 Jyväskylä, Finland

Full list of author information is available at the end of the article
Furthermore, lower mortality rates were reported in patients who responded to methotrexate and lower work disability rates were noted in patients who responded to anti-rheumatic drugs [4].

Although improvements were seen in clinical outcomes, it was a long time before studies showed changes in the rates of TJR. Only in the last 10 years have studies from Western countries and Japan suggested that rates of TJR and other RA-related surgeries have been stable or decreased in patients with RA [5-13], as now reported also by Hekmat and colleagues [1]. Declining trends of TJR surgeries in patients with RA contrasts with a remarkable phenomenon of the increase in overall rates of TJR surgery of the knee or hip documented in the general population of many countries having doubled since 1990, and increased threefold since the early 1980s $[5,14,15]$.

Hekmat and colleagues [1] identified prevalent cases with RA in 1997 and incident cases from 1997 to 2007 in a community-based register in Malmö, Sweden, and linked them to the Swedish hip and knee arthroplasty registers. The incidence of a primary TJR of the hip or knee in 1998-2001 (before tumor necrosis factor inhibitors were available for the treatment of RA) was compared with that in 2002-2006/07 (after these inhibitors became available). A decline was seen in the incidence of the primary hip TJR from 12.6 to 6.6 per 1,000 person-years, whereas a slight trend toward an increase of primary TJR of the knee was observed.

What does this study teach us? First, this study provides further evidence of improving outcomes of RA. TJR of the hip or knee is a severe long-term outcome for patients with RA and accounts for a substantial component of the costs of this disease [16]. Overall rates of TJR surgery of the hip or knee in general population have been documented to have been doubled since 1990 and increased threefold since the early 1980s in many countries. These findings indicate an increased need, associated with aging of the population, for TJR surgery in the population and apparently availability of greater resources to perform these procedures. Therefore, if patients with RA would need TJR surgeries, resources 
would be available in many countries. Second, this study, like many other Swedish and Scandinavian studies [17], is an excellent example of the value of national registers and their use in epidemiological research. The observations by Hekmat and colleagues [1] emphasize the benefits of active treatment strategies for patients with RA. Advances in RA would allow future availability of resources for TJR surgery for the increasing number of people with osteoarthritis in aging populations. Finally, Hekmat and colleagues [1] report promising observations from a developed country with a long history of national registers and availability of biologic treatments for RA. We must recognize that many societies are not as fortunate. Worldwide, many patients with RA, perhaps the majority of them, still suffer from severe RA [18], and measures are needed to improve outcomes of all patients with RA in all countries.

\section{Abbreviations}

$\mathrm{RA}$, rheumatoid arthritis; TJR, total joint replacement.

\section{Competing interests}

The authors declare that they have no competing interests.

\section{Author details}

'University of Arkansas for Medical Sciences \& Central Arkansas Veterans Healthcare System, 4301 W. Markham, \#509, Little Rock, AR 72211, USA. ${ }^{2}$ Arkisto/Tutkijat, Jyväskylä Central Hospital, 40620 Jyväskylä, Finland.

Published: 19 October 2011

\section{References}

1. Hekmat K, Jacobsson L, Nilsson JÅ, Petersson IF, Robertsson O, Garellick G, Turesson C: Decrease in the incidence of total hip arthroplasties in patients with rheumatoid arthritis - results from a well defined population in south Sweden. Arthritis Res Ther 2011, 13:R67.

2. Wolfe F, Zwillich SH: The long-term outcomes of rheumatoid arthritis: a 23-year prospective, longitudinal study of total joint replacement and its predictors in 1,600 patients with rheumatoid arthritis. Arthritis Rheum 1998, 41:1072-1082.

3. Pincus $\mathrm{T}$, Sokka T, Kautiainen $\mathrm{H}$ : Patients seen for standard rheumatoid arthritis care have significantly better articular, radiographic, laboratory, and functional status in 2000 than in 1985. Arthritis Rheum 2005, 52:1009-1019.

4. Puolakka K, Kautiainen H, Möttönen T, Hannonen P, Korpela M, Hakala M, Järvinen P, Ahonen J, Forsberg S, Leirisalo-Repo M; FIN-RACo Trial Group: Early suppression of disease activity is essential for maintenance of work capacity in patients with recent-onset rheumatoid arthritis: five-year experience from the FIN-RACo trial. Arthritis Rheum 2005, 52:36-41.
5. Sokka T, Kautiainen $H$, Hannonen P: Stable occurrence of knee and hip total joint replacement in Central Finland between 1986 and 2003: an indication of improved long-term outcomes of rheumatoid arthritis. Ann Rheum Dis 2007, 66:341-344.

6. da Silva E, Doran MF, Crowson CS, O'Fallon WM, Matteson EL: Declining use of orthopedic surgery in patients with rheumatoid arthritis? Results of a long-term, population-based assessment. Arthritis Rheum 2003, 49:216-220.

7. Ward MM: Decreases in rates of hospitalizations for manifestations of severe rheumatoid arthritis, 1983-2001. Arthritis Rheum 2004, 50:1122-1131.

8. Kobelt G, Eberhardt K, Geborek P: TNF inhibitors in the treatment of rheumatoid arthritis in clinical practice: costs and outcomes in a follow up study of patients with RA treated with etanercept or infliximab in southern Sweden. Ann Rheum Dis 2004, 63:4-10.

9. Weiss RJ, Stark A, Wick MC, Ehlin A, Palmblad K, Wretenberg P: Orthopaedic surgery of the lower limbs in 49,802 rheumatoid arthritis patients: results from the Swedish National Inpatient Registry during 1987 to 2001. Ann Rheum Dis 2006, 65:335-341.

10. Kolling C, Herren DB, Simmen BR, Goldhahn J: Changes in surgical intervention patterns in rheumatoid arthritis over 10 years in one centre. Ann Rheum Dis 2009, 68:1372-1373.

11. Louie GH, Ward MM: Changes in the rates of joint surgery among patients with rheumatoid arthritis in California, 1983-2007. Ann Rheum Dis 2010, 69:868-871.

12. Weiss RJ, Ehlin A, Montgomery SM, Wick MC, Stark A, Wretenberg P: Decrease of RA-related orthopaedic surgery of the upper limbs between 1998 and 2004: data from 54,579 Swedish RA inpatients. Rheumatology (Oxford) 2008, 47:491-494.

13. Fevang BT, Lie SA, Havelin LI, Engesaeter LB, Furnes O: Reduction in orthopedic surgery among patients with chronic inflammatory joint disease in Norway 1994-2004. Arthritis Care Res 2007, 57:529-532.

14. Puolakka TJ, Pajamaki KJ, Halonen PJ, Pulkkinen PO, Paavolainen P, Nevalainen JK: The Finnish Arthroplasty Register: report of the hip register. Acta Orthop Scand 2001, 72:433-441.

15. Dixon T, Shaw M, Ebrahim S, Dieppe P: Trends in hip and knee joint replacement: socioeconomic inequalities and projections of need. Ann Rheum Dis 2004, 63:825-830

16. Yelin E: Is early intervention worth it? J Rheumato/ Supp/ 2005, 72:36-38.

17. Sokka T: National databases and rheumatology research I: longitudinal databases in Scandinavia. Rheum Dis Clin North Am 2004, 30:851-867.

18. Sokka T, Kautiainen H, Pincus T, Toloza S, da Rocha Castelar Pinheiro G, Lazovskis J, Hetland ML, Peets T, Immonen K, Maillefert JF, Drosos AA, Alten R, Pohl C, Rojkovich B, Bresnihan B, Minnock P, Cazzato M, Bombardieri S, Rexhepi S, Rexhepi M, Andersone D, Stropuviene S, Huisman M, Sierakowski S, Karateev D, Skakic V, Naranjo A, Baecklund E, Henrohn D, Gogus F, et al:: Disparities in rheumatoid arthritis disease activity according to gross domestic product in 25 countries in the QUEST-RA database. Ann Rheum Dis 2009, 68:1666-1672.

doi:10.1186/ar3478

Cite this article as: Khan NA, Sokka T: Declining needs for total joint replacements for rheumatoid arthritis. Arthritis Research \& Therapy 2011, 13:130. 